\title{
KONKURENCYJNOŚĆ TURYSTYCZNA REGIONU WOJEWÓDZTWA ŚWIĘTOKRZYSKIEGO (WYBRANE ZAGADNIENIA)
}

\begin{abstract}
Gospodarka turystyczna to dynamicznie rozwijający się sektor. Szanse jego rozwoju zależą nie tylko od zasobów naturalnych, społecznych, historycznych i kulturowych, lecz także od niezbędnej infrastruktury i polityki rozwoju. Celem niniejszego artykułu jest próba określenia czynników rozwoju turystyki w regionie, które będą uwzględniały współczesne uwarunkowania wynikające między innymi z sytuacji makroekonomicznej, a także warunków wewnętrznych regionu oraz wielowymiarowości turystyki. Formą działalności, która podnosi konkurencyjność miast i obszarów, jest turystyka, dzięki której wiele produktów regionalnych i lokalnych znalazło uznanie w oczach szerokiego grona konsumentów. Turystyka ma wyraźny wymiar przestrzenny i jest instrumentem polityki regionalnej, aktywizacji społeczeństw lokalnych oraz budowy trwałych podstaw rozwoju gospodarczego. Rozwój turystyki jest procesem realizowanym w wyniku interakcji między wieloma czynnikami. Ważną rolę w tym procesie odgrywa polityka realizowana przez stosowne władze, jej założenia, cele, narzędzia. Produkt regionu turystycznego obejmuje koszyk dóbr i usług wytwarzanych przez podmioty skoncentrowane $\mathrm{w}$ regionie turystycznym, zaspokajający kompleksowo potrzeby turystów w miejscu pobytu, a więc pomniejszony o koszty transportu i pośrednictwa. Turyści z różnym natężeniem odwiedzają różne miejsca, co powoduje zarówno pozytywne, jak i negatywne skutki rozwoju. Podniesienie konkurencyjności regionów poprzez rozwój turystyki zależy głównie od dobrej infrastruktury technicznej, bogatych zasobów kulturowych i przyrodniczych oraz od umiejętności ich wykorzystania. Oceniając rozwój sektora turystycznego w województwie świętokrzyskiego w ostatnich latach, można stwierdzić, że stało się ono bardzo atrakcyjne dla różnorodnych inwestycji związanych z tworzeniem bazy turystycznej. Wpływ na to miały przede wszystkim dynamiczny rozwój Targów Kielce, liczne atrakcje i produkty turystyczne oraz intensywna promocja województwa w kraju i za granicą.
\end{abstract}

Slowa kluczowe: konkurencyjność, turystyka, produkt turystyczny, region turystyczny

\section{WSTEP}

Gospodarka turystyczna to dynamicznie rozwijający się sektor, zdolny do wchłonięcia znacznych i zróżnicowanych zasobów ludzkich, także na obszarach słabo rozwiniętych. Szanse jego rozwoju zależą nie tylko od zasobów naturalnych i kulturowych, lecz także od niezbędnej infrastruktury i odpowiedniej polityki rozwoju. Większa część polskiego terytorium nie dysponuje zasobami pozwalającymi na rozwój turystyki jedynie na swojej podstawie, co oznacza, że tereny te zależne są od zdolności do wykreowania produktów turystycznych i włączenia się we wspólne projekty z ośrodkami w nie zasobniejszymi. Działania państwa powinny się koncentrować na obszarach już atrakcyjnych turystycznie,

\footnotetext{
${ }^{1}$ Dr Paweł Dziekański, Zakład Przedsiębiorczości i Innowacji, Instytut Ekonomii i Admiracji, Wydział Zarządzania i Administracji, Uniwersytet Jana Kochanowskiego, e-mail: pdziekan@interia.eu.
} 
wzmacniając ich pozycją konkurencyjną i wspierając tworzenie sieci współpracy (dyfuzją na pozostałe tereny) ${ }^{2}$.

Turystyka jest instrumentem polityki regionalnej, aktywizacji społeczeństw lokalnych oraz budowy trwałych podstaw rozwoju gospodarczego. Od jej funkcjonowania zależy nie tylko istnienie wielu gałęzi gospodarki, ale także budowa świadomości społecznej, identyfikacji regionalnej ludności, budowa korzystnych postaw społecznych. Turystyka uznawana jest $\mathrm{z}$ jednej strony za szansę na zachowanie i wykorzystanie różnorodności krajobrazu i dziedzictwa kulturowego województwa, z drugiej - daje możliwość poprawy sytuacji gospodarczej regionu, co w szczególności dotyczy rynku pracy (atrakcyjne miejsca pracy) ${ }^{3}$. Turystyka utożsamiana jest ze stosunkowo łatwą do wdrożenia działalnością, mogącą stać się solidnym wsparciem, a nawet siłą napędową miejscowej gospodarki, przyczyniając się do zwiększania dochodów miejscowej ludności czy zmniejszania bezrobocia.

W warunkach gospodarki wolnorynkowej oraz swobody przemieszczania się i wyboru miejsca docelowego podróży obszary recepcji turystycznej są zmuszone do zabiegania o turystów. Celem niniejszego artykułu jest próba określenia czynników rozwoju turystyki w regionie, które będą uwzględniały współczesne uwarunkowania wynikające między innymi z sytuacji makroekonomicznej, a także warunków wewnętrznych regionu oraz wielkowymiarowości turystyki.

\section{TURYSTYKA}

Turystyka zarówno w ujęciu społecznym, jak i ekonomicznym w wielu gminach i powiatach, a także województwach staje się istotnym obszarem, w którym realizowany jest rozwój gospodarczy. Ma ona wyraźny wymiar przestrzenny: turyści z różnym natężeniem odwiedzają różne miejsca, co powoduje, że zarówno pozytywne, jak i negatywne skutki rozwoju turystyki w różnym stopniu są udziałem różnych miejsc i społeczności.

Szanse rozwoju turystyki tradycyjnie przypisuje się kluczowym zasobom endogenicznym, posiadanym przez daną społeczność (zwłaszcza przyrodniczym i kulturowym) ${ }^{4}$. Rozwój turystyki jest procesem kształtowanym w wyniku interakcji między wieloma czynnikami dotyczącymi środowiska społecznego, przyrodniczego i gospodarczego oraz oceny potrzeb i możliwości wpływania na ich zmianę. Ważną rolę w tym procesie odgrywa polityka realizowana przez stosowne władze, jej założenia, cele, narzędzia. Rozwój turystyki wiąże się z ujawnianiem różnych interesów, prowadzących do konfliktów wokół celów i sposobów rozwoju. Uzgadnianie różnic interesów to stały problem każdej polityki rozwoju, nie wyłączając polityki turystycznej ${ }^{5}$. Rozpatrywanie rozwoju turystyki w jej uwarunkowaniach gospodarczych i społecznych jest celowe ze względu na to, że ze względu na posiadane zasoby turystyczne oraz ich wykorzystywanie w polityce rozwoju regionalnego i lokalnego.

\footnotetext{
${ }^{2}$ M.W. Kozak, Konkurencyjność turystyczna polskich regionów, „Studia Regionalne i Lokalne” 3/25 (2006). http://www.studreg.uw.edu.pl/pdf/3_2006/Kozak_3_2006.pdf(dostęp: 05.03.2014).

${ }^{3}$ Wplyw ustug turystycznych na rozwój gospodarczy regionu, http://www.ewaluacja.gov.pl/Wyniki/Documents/Wplyw_uslug_turystycznych_na_rozwoj_gosp_regionu_030 620123.pdf (dostęp: 05.03.2014).

4 M.W. Kozak, Turystyka i polityka turystyczna a rozwój: między starym a nowym paradygmatem, http://www.publio.pl/files/samples/73/9b/ef/48783/Turystyka_i_polityka_turystyczna_demo.pdf (dostęp: 10.03.2014).

${ }^{5}$ Ibidem.
} 
Jednym z możliwych sposobów doskonalenia jakości i wdrażania innowacyjności w turystyce jest partnerstwo publiczno-prywatne, rozumiane jako nowa forma zarządzania procesami społeczno-gospodarczymi, oparta na wzajemnym zrozumieniu i wspieraniu się kapitału prywatnego i publicznego. Jakość w turystyce może być bowiem udoskonalona tylko w wypadku zgodnej realizacji wspólnie wytyczonych celów z zapewnieniem wieloaspektowego spojrzenia na sposoby ich osiągnięcia i znalezienia wspólnie wdrażanych środków (w tym finansowych). Tylko współdziałanie może zapewnić przewagę konkurencyjną rynku usług turystycznych regionu w stosunku do innych sektorów z jednej strony oraz rynku europejskiego - z drugiej ${ }^{6}$.

\section{REGION TURYSTYCZNY I PRODUKT TURYSTYCZNY}

Analiza turystycznych jednostek pozwala traktować region jako system powiązanych ze sobą podmiotów i obiektów, wyodrębnionych na podstawie funkcji turystycznej ${ }^{7}$. Region turystyczny to obszar spełniający następujące podstawowe warunki: ma określone walory turystyczne, sieć dróg kolejowych, drogowych lub wodnych oraz system połączeń transportowych oraz dysponuje określonym zagospodarowaniem turystycznym ${ }^{8}$.

Region turystyczny (RT) to obszar o podobnym typie krajobrazu, mający określone walory turystyczne, odpowiednie do ich wykorzystania zagospodarowanie turystyczne. Obszar ten, z określonymi w przestrzeni granicami, różni się od otaczających go terenów, na których nie występują wyróżnione wcześniej cechy lub procesy. Głównymi kryteriami wydzielenia regionów turystycznych są walory wypoczynkowe, krajoznawcze, specjalistyczne, dostępność komunikacyjna terenu, jego zagospodarowanie oraz ruch turystyczny. Region turystyczny obejmuje na ogół obszary o wysokich walorach turystycznych i dobrze rozwiniętej infrastrukturze turystycznej i dostępności komunikacyjnej ${ }^{9}$. Podejście ekonomiczne cechuje uznanie koegzystencji przestrzeni geograficznej (środowiska naturalnego, gospodarczego, społecznego) oraz społeczno-ekonomicznej jako siły sprawczej wykształcenia się regionów turystycznych. Zgodnie z nim jest to obszar pełniący funkcję turystyczną na zasadzie pewnej jednorodności cech środowiska geograficznego oraz wewnętrznych powiązań usługowych ${ }^{10}$.

Produkt regionu turystycznego obejmuje koszyk dóbr i usług wytwarzanych przez podmioty skoncentrowane $\mathrm{w}$ regionie turystycznym, zaspokajający kompleksowo potrzeby turystów w miejscu pobytu, a więc pomniejszony o koszty transportu i pośrednictwa ${ }^{11}$. Jest on zintegrowanym układem oczekiwań, korzyści i wrażeń tworzących niepowtarzalną kompozycję trzech podróży: wyobrażonej, rzeczywistej i zapamiętanej ${ }^{12}$.

Produkt turystyczny obszaru można następująco scharakteryzować: 1) jest zdeterminowany przestrzennie - to wypadkowa środowiska geograficznego, dziedzictwa historycznego i kulturowego danego obszaru; 2) jest złożony - to zbiór pewnej liczny elemen-

\footnotetext{
${ }^{6}$ Ibidem, s. 37.

${ }^{7}$ P. Zmyślony, Partnerstwo i przywództwo w regionie turystycznym, Wydawnictwo AE, Poznań 2008, s. 11.

${ }^{8}$ A.S. Kornak, Zarzadzanie turystyka i jej podmiotami w miejscowości i regionie, Wydawnictwo AE, Wrocław 2001, s. 45

${ }^{9}$ Por. J. Warszyńska, A. Jackowski, Podstawy geografii turyzmu, PWN, Warszawa 1978, s. 31.

${ }^{10}$ Ibidem.

${ }^{11}$ Ibidem, s. 19.

${ }^{12}$ J. Kaczmarek, Produkt turystyczny. Pomyst. Organizacja. Zarządzanie, Polskie Wydawnictwo Ekonomiczne, Warszawa 2005.
} 
tów oraz ich wzajemnych, wieloaspektowych relacji; 3) jest multiwytwarzalny - ma wielu wytwórców; 4) jest komplementarny - elementy produktu wzajemnie się dopełniają i kreują wspólną wiązkę korzyści dla turysty; 5) jest synergiczny - zintegrowane działania wielu podmiotów kreujących produkt zmniejszają koszty jego przygotowania i promocji, a zwiększają szanse rynkowego sukcesu; 6) jest silnie uzależniony od trudnych do przewidzenia czynników psychospołecznych - takich jak moda, cele i motywacje podróży, indywidualne przyzwyczajenia; 7) nie ma jednej ceny i jednego standardu oraz 8) konsumpcja tego produktu może być rozłożona $\mathrm{w}$ czasie $^{13}$.

Produkt turystyczny może obejmować dobra materialne, usługi, dobra związane z usługami (najczęściej jako względem nich komplementarne), a także całą wiązkę wartości niematerialnych (doznań, odczuć, emocji) będących rezultatem zarówno uczestniczenia w samym wyjeździe, jak i związanych z obcowaniem z bliskim i dalszym otoczeniem imprezy turystycznej ${ }^{14}$.

Gmina Zagnańsk jako logo produktu turystycznego może wykorzystywać motyw dębu, który stosowano od epoki średniowiecza w królewskich i rycerskich herbach rodowych ze względu na jego majestat i dostojny wygląd ${ }^{15}$. Innym produktem jest tetrapod odkryty w Zachełmiu najstarszy na świecie ślad czworonoga, który po raz pierwszy postawił stopę na suchym lądzie ${ }^{16}$. Produktem turystycznym są także kościoły, na przykład $\mathrm{w}$ Tumlinie wybudowany $\mathrm{z}$ czerwonego piaskowca w stylu wczesnobarokowym ${ }^{17}$. Kościół w Zachełmiu zbudowano z bloków dolomitowych, składa się on z prezbiterium, nawy i dzwonnicy. Do dziś zachowały się barokowe ołtarze boczne, a w kopule polichromia przedstawia sceny z życia świętej Rozalii i świętego Marcina. W wypadku gminy Ostrowiec Świętokrzyski produktem turystycznym są: Kolegiata św. Michała Archanioła, kościół św. Stanisława Biskupa w dzielnicy Denków, zespół pałacowo-parkowy w dzielnicy Częstocice $\mathrm{z}$ dawnym pałacem hrabiów Wielopolskich, pałac myśliwski hrabiów Wielopolskich, drewniany kościół Najświętszego Serca Jezusowego przy ulicy Sandomierskiej, zajazd pocztowy z przełomu XVIII i XIX w. na ulicy Szerokiej, cmentarz żydowski, gmach poczty na Alei 3 Maja, budynek dawnej ubezpieczalni społecznej z 1931 na ulicy Focha, dworzec kolejowy z końca XIX w. oraz figura świętego Floriana z 1776 r.

\section{KONKURENCYJNOŚĆ TURYSTYCZNA REGIONÓW}

Konkurencyjność turystyczna regionu to trwała zdolność do konkurowania i podnoszenia korzyści z turystyki, przy czym korzyści te powinny dotyczyć całego układu społeczno-ekonomicznego ${ }^{18}$. Poszczególne miejscowości czy regiony, odpowiednio do swoich zasobów i potrzeb, przystępują do rywalizacji na różnych płaszczyznach: atrakcyjno-

\footnotetext{
${ }^{13}$ Ibidem.

${ }^{14}$ B. Marciszewska, Produkt turystyczny a ekonomia doświadczeń, C.H. Beck, Warszawa 2010, s. 66.

${ }^{15}$ Zob. Motyw dębu w herbach, http://www.petrio.pl/tag/herby-krolewskie (dostęp: 8.05.2013); P. Dziekański, A. Olak, S. Pytka, Marketing terytorialny. Gmina i jej promocja, MULTIPRINT, s.r.o Košice, Wyższa Szkoła Biznesu i Przedsiębiorczości w Ostrowcu Św., Ostrowiec Św. - Košice - Zagnańsk 2014.

${ }^{16}$ Zob.: Kraina Tetrapoda, http://kraina-tetrapoda.pl/ (dostęp: 18.05.2013).

${ }^{17}$ M. Starz, Zagnańsk, Samsonów, Tumlin, Ćmińsk. Z dziejów osad nad Górną Bobrzą, Agencja „JP”, Kielce 1995, s. 19.

${ }^{18}$ G. Crouch, I. Ritchie, J.R. Brent, Tourism, Competitiveness and Societal Prosperity, „Journal of Buisness Research” 1999/44; G. Crouch, I. Ritchie, The competitive destination: a sustainability perspective, „Tourism Management” 21/1 (2000).
} 
ści inwestycyjnej, infrastruktury transportowej czy kształtowania poziomu życia mieszkańców. Miejscowości i regiony również coraz częściej konkurują o pozyskanie turystów. Włączenie się do rywalizacji o turystów wydaje się o tyle łatwe, że czasem wystarczy zadbać o środowisko przyrodnicze i dziedzictwo kulturowe, historyczne, aby stworzyć podstawy rozwoju turystyki. Regiony takie, chcąc zaistnieć bądź utrwalić swoją pozycję na rynku, muszą jednak zatroszczyć się o kształtowanie poszczególnych aspektów decydujących o tym, że będą konkurencyjne w rywalizacji toczonej z innymi tego rodzaju podmiotami $^{19}$.

Podniesienie konkurencyjności regionów poprzez rozwój turystyki zależy głównie od dobrej infrastruktury technicznej, bogatych zasobów kulturowych i przyrodniczych oraz od umiejętności ich wykorzystania. Identyfikacja unikatowych walorów środowiska przyrodniczego i kulturowego może stanowić podstawę wykreowania markowych produktów turystycznych, mogących konkurować z produktami markowymi innych jednostek i być pożądaną ofertą dla turystów zagranicznych.

Silne włączenie turystyki w podnoszenie konkurencyjności regionów wymaga podjęcia przez samorząd wielu działań: w zakresie marketingu (strategia marketingowa, plan kreacji marki, informacja turystyczna), kapitału ludzkiego (integracja społeczności wokół turystyki, przewodnicy turystyczni, informatorzy turystyczni, kadra turystyczna regionu), instytucji (wsparcie i rozwój podmiotów, branży turystycznej i okołoturystycznej, partnerstwo na rzecz turystyki), produktu turystycznego (plan kreacji produktu, strategia promocji produktu, rozwój produktu), przestrzeni turystycznej (ochrona walorów środowiska naturalnego, kultur i historii, rozwój infrastruktury turystycznej i okołoturystycznej) ${ }^{20}$.

\section{TURYSTYKA W REGIONIE ŚWIĘTOKRZYSKIM}

Jednym z charakterystycznych elementów trwającego obecnie w Polsce procesu przechodzenia do myślenia w kategoriach nowego paradygmatu rozwoju turystyki jest coraz wyraźniejsze różnicowanie sposobów rozumienia turystyki na dwa alternatywne, a zarazem komplementarne podejścia: turystyka jako zjawisko (proces) społeczny oraz turystyka jako źródło nowych miejsc pracy i dochodów (gospodarka turystyczna) ${ }^{21}$.

Turystyka ma wyraźny wymiar przestrzenny: turyści z różnym natężeniem odwiedzają różne miejsca, co powoduje, że zarówno pozytywne, jak i negatywne skutki rozwoju turystyki w innym stopniu są udziałem różnych miejsc i społeczności. Szanse rozwoju turystyki tradycyjnie przypisuje się kluczowym zasobom endogenicznym, posiadanym przez daną społeczność (zwłaszcza przyrodniczym i kulturowym). Wydaje się, że obraz ten jest obecnie nazbyt uproszczony i nie wyjaśnia dostatecznie przyczyn rozwoju turystyki lub jego braku² ${ }^{22}$ Tymczasem rozwój turystyki jest procesem kształtowanym w wyniku interakcji między wieloma czynnikami po obu stronach, a ważną rolę w tym procesie odgrywa polityka realizowana przez stosowne władze, jej założenia, cele, narzędzia.

Zgodnie ze stanem z 31 lipca 2012 r. w województwie świętokrzyskim zarejestrowano 167 obiektów zbiorowego zakwaterowania, spośród których 145 to obiekty całoroczne.

\footnotetext{
${ }^{19}$ Por. J. Grabowski, Uwarunkowania konkurencyjności turystycznej regionów, „Ruch Prawniczy, Ekonomiczny i Socjologiczny” LXX/3 (2008).

${ }^{20}$ Ibidem.

${ }^{21}$ Turystyka jako czynnik rozwoju regionów Polski Wschodniej, http:/monitoruj.podkarpackie.pl/assets/files/ bazawiedzy/analizy,\%20ekspertyzy/KOZAK_TURYSTYKA_PL_WSCH_18_10_2011.pdf (dostęp: 10.03.2014).

${ }^{22}$ Ibidem.
} 
Bazę turystyczną tworzyło 107 obiektów hotelarskich oraz 60 pozostałych obiektów noclegowych turystyki ${ }^{23}$.

W turystycznych obiektach zbiorowego zakwaterowania w 2012 r. udzielono 1330,9 tys. noclegów, czyli o $6,6 \%$ więcej niż przed rokiem. Najwięcej noclegów udzielono w hotelach - 571,9 tys. (43,0\% ogólnej liczby) oraz zakładach uzdrowiskowych - 464,5 tys. (34,9\% całości). Osoby odwiedzające województwo świętokrzyskie w 2012 r. najczęściej korzystały z noclegów w Kielcach - 112,5 tys. (25,8\% ogółu korzystających w województwie), w powiecie kieleckim 84,2 tys. (19,3\%), a także w powiecie buskim - 51,6 tys. $(11,8 \%)$ i sandomierskim - 42,1 tys. $(9,7 \%)$. Zdecydowana większość turystów korzystała z usług obiektów hotelowych (rys. 1).

Rys. 1. Struktura turystycznych obiektów zbiorowego zakwaterowania w 2012 r.

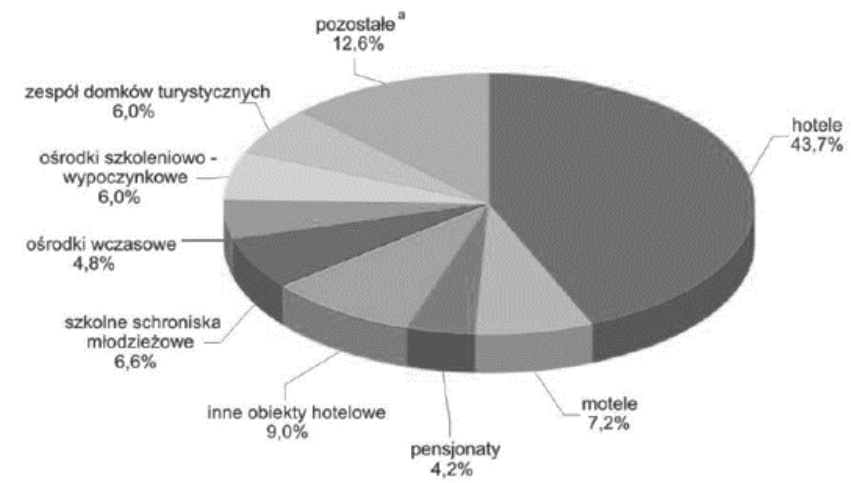

Źródło: http://www.stat.gov.pl/cps/rde/xbcr/kielce/ASSETS_TURYSTYKA_2013.pdf (09.05.2014)

Ponad 40\% z ogólnej liczby noclegów udzielono w powiecie buskim - 589,7 tys., z czego tylko 19,7\% w obiektach hotelowych. Pod względem liczby udzielonych noclegów wyróżniały się również: miasto Kielce - 198,7 tys. (14,7\% ogółu udzielonych noclegów w województwie) i powiat kielecki - 192,5 tys. (14,3\%) (rys. 2).

\footnotetext{
${ }^{23}$ Turystyka w województwie świętokrzyskim w 2012 r., http://www.stat.gov.pl/cps/rde/xbcr/kielce/ ASSETS_TURYSTYKA_2013.pdf (dostęp: 15.03.2014).
} 
Rys. 2. Korzystający z noclegów w obiektach zbiorowego zakwaterowania w 2012 r.

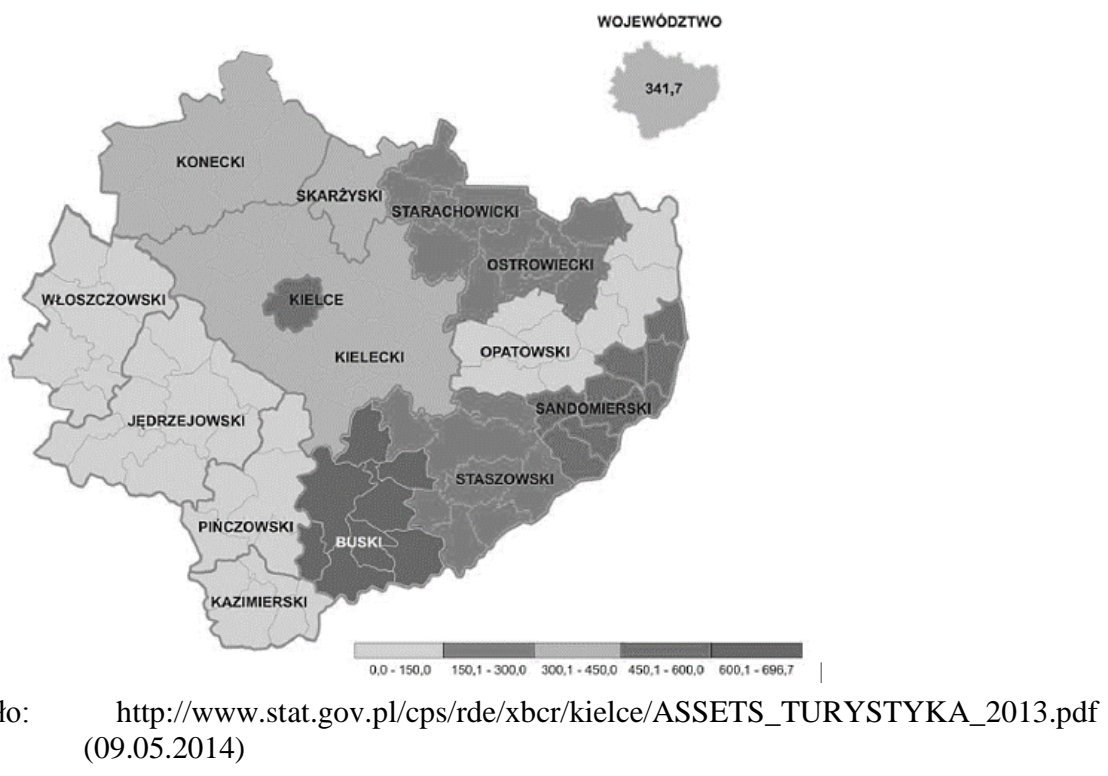

W roku 2012 odnotowano wzrost liczby turystów z zagranicy. Na teren województwa świętokrzyskiego przybyło 29,1 tys. cudzoziemców, czyli o 3,8\% więcej niż w 2011 r. Udzielono im 64,0 tys. noclegów (o 2,3\% mniej niż w 2011 r.). Zdecydowana liczba obcokrajowców korzystała z noclegów w hotelach $(84,2 \%)^{24}$.

Najwięcej osób na teren województwa przyjechało z Niemiec, stanowili oni $14,0 \%$ ogólnej liczby gości zagranicznych (w 2011 r. - 15,4\%). Znaczący udział w ogólnej liczbie gości zagranicznych stanowili również mieszkańcy Ukrainy $(11,8 \%)$, Izraela $(10,2 \%)$, Włoch (6,6\%) oraz Francji (5,6\%), Rosji (5,5\%) i Wielkiej Brytanii (5,1\%). Nadal największa liczba obcokrajowców na miejsce swojego pobytu wybierała Kielce $(40,9 \%)$. Ich udział był mniejszy niż rok wcześniej o 3,4 pkt. proc.

\section{PODSUMOWANIE}

Obserwując zmiany zachodzące w Polsce i na świecie, można zauważyć, że to aktywność mieszkańców, w zakresie wybranej formy działalności przyczynia się do promocji, rozpoznawalności i w konsekwencji do poprawy konkurencyjności danego miejsca. Formą działalności, która podnosi konkurencyjność miast i obszarów, jest turystyka.

Podniesienie konkurencyjności regionów poprzez rozwój turystyki zależy głównie od dobrej infrastruktury technicznej, bogatych zasobów kulturowych i przyrodniczych oraz od umiejętności ich wykorzystania. Identyfikacja unikatowych walorów środowiska przyrodniczego i kulturowego może stanowić podstawę wykreowania markowych produktów turystycznych, mogących konkurować z produktami markowymi innych województw i być pożądaną ofertą dla turystów zagranicznych.

\footnotetext{
${ }^{24}$ Ibidem.
} 
Turystyka jest jednym z najszybciej rozwijających się sektorów i jedną z nielicznych dziedzin, w której wzrost wpływów przekłada się na tworzenie realnych miejsc pracy. Jest jednocześnie potężnym instrumentem polityki regionalnej, pozwalającym na wyrównywanie różnic społeczno-ekonomicznych. Dzięki turystyce różne narody maja okazję się poznać i zrozumieć, przełamywać stereotypy, wzbogacać wiedzę, rozwijać się intelektualnie. Jest doskonałą podstawą do aktywizacji społeczeństw lokalnych i rozwoju regionów.

Konkurencyjność wynika z atutów, czyli najważniejszych silnych stron regionu, których źródło tkwi między innymi w systemie edukacyjnym, strukturze gospodarczej i infrastrukturze. Jest ona postrzegana jako trwała przewaga jednego regionu nad innymi lub też jako dystans, jaki dzieli jeden region od innego. Konkurencyjność regionu turystycznego jest zdolnością podmiotów, czyli jednostek terytorialnych, do rywalizacji o różne korzyści, na przykład o dostęp do środków finansowych czy inwestycji.

Oceniając rozwój sektora turystycznego w województwie świętokrzyskim w ostatnich latach, można stwierdzić, że stało się ono bardzo atrakcyjne dla różnorodnych inwestycji związanych z tworzeniem bazy turystycznej. Wpływ na to miały przede wszystkim dynamiczny rozwój Targów Kielce, liczne atrakcje i produkty turystyczne (Bałtów, Baseny Mineralne Solec-Zdrój, Bobrza, Bodzentyn, Chęciny Ciekoty i przełom rzeki Lubrzanki, Jaskinia Raj, Kałków-Godów - Sanktuarium Matki Bożej Bolesnej Królowej Polski Matki Ziemi Świętokrzyskiej, Maleniec, Nowa Słupia, Oblęgorek, Samsonów, Sandomierz, Święta Katarzyna, Święty Krzyż) oraz intensywna promocja województwa w kraju i za granicą.

Rozwój turystyki zależy zarówno od czynników społecznych, jak i technologicznych. Wraz z bogaceniem się społeczeństw rośnie popyt na produkty turystyczne. Również rozwój ekonomiczno-społeczny, istnienie międzynarodowych powiązań gospodarczych, globalnej konkurencji i globalnych rynków wymuszają konieczność podróżowania w celach służbowych ${ }^{25}$

\section{LITERATURA}

[1] Crouch G., Ritchie I., Brent J.R., Tourism, Competitiveness and Societal Prosperity, „Journal of Buisness Research” 1999/44.

[2] Crouch G., Ritchie I., The competitve destination: A sustainability perspective, „Tourism Management” 21/1 (2000).

[3] Dziekański P., Olak A., Pytka S., Marketing terytorialny. Gmina i jej promocja Marketing terytorialny. Gmina i jej promocja, MULTIPRINT, s.r.o Košice, Wyższa Szkoła Biznesu i Przedsiębiorczości w Ostrowcu Św., Ostrowiec Św. - Košice - Zagnańsk 2014.

[4] Grabowski J., Uwarunkowania konkurencyjności turystycznej regionów, „Ruch Prawniczy, Ekonomiczny i Socjologiczny” LXX/3 (2008).

[5] Kaczmarek J., Produkt turystyczny. Pomyst. Organizacja. Zarzadzanie, Polskie Wydawnictwa Ekonomiczne, Warszawa 2005.

[6] Kornak A.S., Zarzadzanie turystyka i jej podmiotami w miejscowości i regionie, Wydawnictwo AE, Wrocław 2001.

[7] Kozak M.W., Konkurencyjność turystyczna polskich regionów, „Studia Regionalne i Lokalne” $3 / 25$ (2006), http://www.studreg.uw.edu.pl/pdf/3_2006/Kozak_3_2006.pdf (dostęp: 05.03.2014)

\footnotetext{
${ }^{25}$ Strategia rozwoju turystyki w województwie świętokrzyskim na lata 2006-2014, http://www.rot. swietokrzyskie.travel/data/Pliki/1_strategia.rozwoju.turystyki.pdf (dostęp: 15.02.2014).
} 
[8] Kozak M.W., Turystyka i polityka turystyczna a rozwój: między starym a nowym paradygmatem, http://www.publio.pl/files/samples/73/9b/ef/48783/Turystyka_i_polityka_turystyczna_demo.p df (dostęp: 10.03.2014).

[9] Kraina Tetrapoda, http://kraina-tetrapoda.pl/ (dostęp: 18.05.2013).

[10] Labuzík M., Olak A., Európska únia Vybrané témy, WSBiP w Ostrowcu Świętokrzyskim, Ostrowiec Świętokrzyski 2013.

[11] Marciszewska B., Produkt turystyczny a ekonomia doświadczeń, C.H. Beck, Warszawa 2010.

[12] Motyw dębu w herbach, http://www.petrio.pl/tag/herby-krolewskie (dostęp: 8.05.2013).

[13] Panasiuk A., Ekonomika turystyki, Wydawnictwo Naukowe PWN, Warszawa 2006.

[14] Pawlik A., Zróżnicowanie rozwoju społeczno-gospodarczego w województwie świętokrzyskim, „Wiadomości Statystyczne” 11, PTS, Główny Urząd Statystyczny, Warszawa 2011, s. 60-70.

[15] Puchnarewicz E., Wpływ turystyki na społeczności lokalne. Doświadczenia krajów rozwijajacych się, [w:] Turystyka i rekreacja, Wyższa Szkoła Turystyki i Języków Obcych w Warszawie, 2008/1.

[16] Sikorska-Wolak I., Potencjat turystyczny w regionach, http://keekid.wne.sggw.pl/wpcontent/uploads/2013/01/Potencjał-turystyczny-w-regionach.pdf (dostęp: 10.03.2014).

[17] Starz M., Zagnańsk, Samsonów, Tumlin, Ćmińsk. Z dziejów osad nad Górna Bobrza, Agencja „JP”, Kielce 1995.

[18] Strategia rozwoju turystyki w województwie świętokrzyskim na lata 2006-2014, http://www.rot.swietokrzyskie.travel/data/Pliki/1_strategia.rozwoju.turystyki.pdf (dostęp: 15.02.2014).

[19] Sowa B., Budżet jednostki samorządu terytorialnego jako podstawa planowania przedsięwzięć inwestycyjnych, [w:] Przedsiębiorczość. Uwarunkowania i przejawy w procesie funkcjonowania samorzadu terytorialnego, red. K. Jaremczuk, L. Kliszczak i in., „Podręczniki Uczelniane” 113, Wyższa Szkoła Prawa i Administracji w Przemyślu, Przemyśl-Rzeszów 2012, s. 131-157.

[20] Sowa B., Analiza dochodów własnych jednostek samorzadu terytorialnego (ze szczególnym uwzględnieniem podatków i opłat lokalnych) na przykładzie na przykładzie Gminy Biłgoraj, „Zeszyty Naukowe Szkoły Głównej Gospodarstwa Wiejskiego w Warszawie”, „Ekonomika i Organizacja Gospodarki Żywnościowej”, Warszawa 2010/81, s. 147-156.

[21] Sowa B., Polityka regionalna wobec integracji Polski z Unia Europejska [w:] Prawo - Administracja - Gospodarka po 15 latach transformacji ustrojowej, red. J. Szreniawski, Wyższa Szkoła Administracji i Zarządzania w Przemyślu, Przemyśl 2006.

[22] Turystyka jako czynnik rozwoju regionów Polski Wschodniej, http://monitoruj.podkarpackie.pl/assets/files/bazawiedzy/analizy,\%20ekspertyzy/KOZAK_TU RYSTYKA_PL_WSCH_18_10_2011.pdf(dostęp: 10.03.2014).

[23] Turystyka w województwie świętokrzyskim w 2012 r., http://www.stat.gov.pl/cps/rde/xbcr/kielce/ASSETS_TURYSTYKA_2013.pdf (dostęp: 15.03.2014).

[24] Warszyńska J., Jackowski A., Podstawy geografii turyzmu, PWN, Warszawa 1978.

[25] Wplyw ustug turystycznych na rozwój gospodarczy regionu, http://www.ewaluacja.gov.pl/Wyniki/Documents/Wplyw_uslug_turystycznych_na_rozwoj_go sp_regionu_030620123.pdf(dostęp: 5.03.2014).

[26] Zmyślony P., Partnerstwo i przywództwo w regionie turystycznym, Wydawnictwo AE, Poznań 2008.

\section{THE TOURISM COMPETITIVENESS OF THE ŚWIĘTOKRZYSKIE REGION (SELECTED ISSUES)}

Tourism is a rapidly growing sector. It is able to absorb significant and human resources, also on the underdeveloped areas. The chances of its development depend not only on the natural and cultural resources, but also on the necessary infrastructure and an ade- 
quate development policy. The purpose of this article is to attempt to determine the factors of tourism development in the region, which will take into account, inter alia, contemporary conditions the macroeconomic situation and the internal conditions of the region and the multidimensionality of tourism. The activity that raises the competitiveness of cities and areas is tourism. Also thanks tourism many local and regional products (including food) found recognition in the eyes of a wide range of consumers. Tourism is an instrument of regional policy, activation of local societies and build a sustainable basis for economic development. Tourism development is a process implemented as a result of the interaction between many factors. An important role in this process is played by the policy implemented by the relevant authorities, its assumptions, goals, tools. Tourism has a clear spatial dimension. Product tourist region covers a basket of goods and services produced by the concentrated in the tourist region, fully meet the need-by tourists in the place of residence, and thus reduced by the costs of transport and brokering. Increasing the competitiveness of the regions through the development of tourism depends mainly on the good technical infrastructure, the rich cultural and natural resources.

Keywords: competitiveness, tourism, tourist product, tourist region

\section{DOI: $10.7862 /$ rz.2014.mmr.15}

Tekst złożono w redakcji: maj 2014

Przyjęto do druku: czerwiec 2014 